\title{
HUBUNGAN PERCAYA DIRI DENGAN HASIL BELAJAR PKn PESERTA DIDIK KELAS V SDN-4 PAHANDUT PALANGKA RAYA
}

\author{
(The Relationship Of Self-Confidence With Learning Result Of Pkn In The Fifth Grade Students Of SDN-4 \\ Pahandut Palangka Raya)
}

\section{MISYANTO}

\author{
Program Studi Pendidikan Guru Sekolah Dasar Fakultas Keguruan dan IImu Pendidikan \\ Universitas Muhammadiyah Palangkaraya \\ JI. RTA Milono Km.1,5 Palangka Raya, Kalimantan Tengah 73111 \\ e mail : misyanto24@gmail.com
}

\begin{abstract}
This study aims to determine the relationship of confidence with the results of learning Civics students Class V SDN-4 Pahandut Even Semester Year Lesson 2016/2017.

The population in this study is all students of class V in SDN-4 Pahandut in the 2016/2017 school year, amounting to 45 people. The sample of this study is the entire study population (population research). Instruments in this study are questionnaires and tests. The method used in this research is correlation method and the analysis used is Product Moment Correlation formula.

Conclusion that there is a relationship Confident with Learning Outcomes Civics Students Class V SDN-4 Pahandut Palangka Raya Lesson 2012/2013. It is based on the results of data analysis is $r$ arithmetic $>$ r table $=0.797>0.248$ (at $5 \%$ significance level).
\end{abstract}

Keywords: Self Confidence, Learning

\section{ABSTRAK}

Penelitian ini bertujuan untuk mengetahui hubungan percaya diri dengan hasil belajar PKn peserta didik Kelas V SDN-4 Pahandut Semester Genap Tahun Pelajaran 2016/2017.

Populasi dalam penelitian ini adlaah seluruh peserta didik kelas V di SDN-4 Pahandut tahun pelajaran 2016/2017 yang berjumlah 45 orang. Sampel penelitian ini adalah seluruh populasi penelitian (penelitian populasi). Instrumen dalam penelitian ini adalah angket dan tes. Metode yang digunakan dalam penelitian ini adalah metode korelasional dan analisis yang digunakan adalah rumus Korelasi Product Moment.

Kesimpulan bahwa ada hubungan Percaya Diri dengan Hasil Belajar PKn Peserta Didik Kelas V SDN-4 Pahandut Palangka Raya Tahun Pelajaran 2012/2013. Hal tersebut berdasarkan pada hasil analisis data yaitu $r$ hitung $>r$ tabel $=0,797>0,248$ (pada taraf signifikansi $5 \%$ ).

Kata Kunci: Percaya Diri, Hasil Belajar PKn.

\section{PENDAHULUAN}

PKn merupakan salah satu mata pelajaran yang harus dipelajari oleh peserta didik dari tingkat SD. Menurut Angreini, dkk. (2000:3), bahwa:Pendidikan Kewarganegaraan adalah mata pelajaran yang digunakan sebagai wahana untuk mengembangkan dan melestarikan nilai demokrasi yang bertujuan untuk mempersiapkan warga masyarakat untuk berpikir kritis dan bertindak demokratis".

Dari pendapat tersebut dapat disimpulkan bahwa Pendidikan Kewarganegaraan adalah pendidikan yang mengkaji dan membahas tentang pemerintahan, lembaga-lembaga, hak 
dan kewajiban warga negara serta bertujuan untuk mengarahkan generasi muda menjadi warga negara yang berpikir kritis, rasional, berbudaya dan bertanggung jawab dalam segala hal.

Mata Pelajaran Pendidikan

Kewarganegaraan bertujuan agar peserta didik memiliki kemampuan berpikir secara kritis, rasional, berpartisipasi secara aktif, bertindak secara cerdas dan bertanggung jawab dalam lingkungan keluarga, masyarakat, bangsa serta negara.

Mata pelajaran PKn dapat membantu peserta didik belajar tentang nilai, moral sopan santun, adat budaya, serta masyarakat sekitarnya dimana mereka hidup dan memperoleh jalan untuk belajar menerima realita sosial, hidup rukun bersama dalam perbedaan, serta membantu mengembangkan keterampilan peserta didik.

Berdasarkan hasil observasi yang dilakukan peneliti di kelas V SDN-4 Pahandut Palangka Raya dengan jumlah peserta didik 45 orang, terlihat bahwa peserta didik sangat kurang percaya diri pada saat mengikuti pelajaran terutama pada mata pelajaran PKn.

Pada saat guru selesai menjelaskan materi pelajaran dan kemudian guru bertanya kepada peserta didik ternyata banyak peserta didik yang diam, tanpa memberikan tanggapan terhadap pertanyaan tersebut. Hal ini terlihat 25\% (11 peserta didik) yang memiliki tingkat percaya diri yang tinggi dan $75 \%$ (34 peserta didik) yang memiliki tingkat percaya diri yang rendah. Hasil tersebut didukung juga dari hasil belajar mata pelajaran PKn peserta didik kelas $V$ SDN-4 Pahandut Palangka Raya masih banyak di bawah Kriteria Ketuntasan Minimal (KKM), yaitu 65\% (30 peserta didik) yang nilainya dibawah KKM dengan nilai 3 sampai dengan 5 dan 35\% (15 peserta didik) sudah mencapai KKM dengan nilai 6 sampai dengan 9. Padahal hasil belajar mata pelajaran PKn peserta didik harus mencapai Kriteria Ketuntasan Minimal (KKM) PKn di SDN-4 Pahandut yaitu 6 .

Berdasarkan uraian tersebut, bahwa rasa percaya diri dalam mata pelajaran $\mathrm{PKn}$ merupakan fenomena yang peneliti temukan, hal demikian tentu saja bertolak belakang dengan tujuan pembelajaran PKn yang sangat mengharapkan perserta didik untuk dapat memahami mata pelajaran sepenuhnya.

Oleh karena itu, peneliti merasa tertarik untuk melakukan penelitian dengan judul "Hubungan Percaya Diri dengan Hasil Belajar PKn Peserta Didik Kelas V SDN-4 Pahandut Palangka Raya".

\section{METODE PENELITIAN}

Metode penelitian yang digunakan dalam penelitian ini adalah metode korelasional, metode korelasional ini adalah penelitian yang melibatkan hubungan antara variabel satu dengan variabel lainnya.

Populasi dalam penelitian ini adalah jumlah keseluruhan peserta didik kelas $\mathrm{Va}$ dan $\mathrm{Vb}$ di SDN-4 Pahandut Palangka Raya Tahun Pelajaran 2016/2017 yang berjumlah 45 orang peserta didik dengan rincian sebagai berikut:

Tabel 1. Populasi Penelitian

\begin{tabular}{llc}
\hline No & Kelas & Jumlah Peserta Didik \\
\hline 1 & VA & 23 \\
\hline 2 & VB & 22 \\
\hline & Total & 45 \\
\hline
\end{tabular}


Sumber : Daftar Hadir Kelas Va dan Vb SDN-4 Pahandut Palangka Raya.

Teknik pengumpulan data dalam penelitian ini menggunakan angket untuk mengambil data percaya diri peserta didik dan tes untuk mengambil data hasil belajar PKn.

\section{HASIL DAN PEMBAHASAN}

Sebelum dilakukan pengujian hipotesis, maka hipotesis penelitian terlebih dahulu dinyatakan ke dalam hipotesis statistik sebagai berikut:

Ho : Tidak ada hubungan Percaya Diri dengan Hasil Belajar PKn Peserta Didik Kelas V SDN-4 Pahandut Palangka Raya.

$\mathrm{Ha}$ : Ada hubungan Percaya Diri dengan Hasil Belajar PKn Peserta Didik Kelas V SDN-4 Pahandut Palangka Raya.

Selanjutnya dilakukan analisis dengan bantuan Korelasi Product Moment dapat dilihat pada tabel 2 :

Adapun hasil uji hipotesis penelitian ini menggunakan perhitungan rumus Korelasi Product Moment sebagai berikut :

Diketahui :

$\sum X=1232$

$\sum Y=3237,5$

$\sum X^{2}=34444$

$\sum Y^{2}=237968,75$

$\sum X Y=90150$

$\mathrm{N}=45$

$$
\begin{aligned}
& r_{\mathrm{xy}}=\frac{N \sum \mathrm{xy}-\left(\sum \mathrm{x}\right)\left(\sum \mathrm{y}\right)}{\sqrt{\left\{\mathrm{N}\left(\sum \mathrm{x}^{2}\right)-\left(\sum x\right)^{2} \int \mathrm{N}\left(\sum \mathrm{y}^{2}\right)-\left(\sum \mathrm{y}\right)^{2}\right\}}} \\
&= \frac{45 \times 90150-1232 \times 3237,5}{\sqrt{\left(45 \times 34444-1232^{2}\right)\left(45 \times 237968,75-3237,5^{2}\right)}} \\
&= \frac{4056750-3988600}{\sqrt{(1549980-1517824)(10708593,75-10481406,25)}} \\
&= \frac{68150}{\sqrt{(32156)(227187,5)}} \\
&=\frac{68150}{\sqrt{7305441250}} \frac{68150}{85471,874} \\
& r_{\mathrm{xy}}=0,797
\end{aligned}
$$

Jadi $r$ hitung sebesar 0,797, maka dapat disimpulkan bahwa Ho ditolak dan Ha diterima yaitu ada hubungan Percaya Diri dengan Hasil Belajar PKn Peserta Didik Kelas V SDN-4 Pahandut Palangka Raya Tahun Pelajaran 2016/2017.

Berdasarkan hasil analisis data menggunakan rumus Korelasi Product Moment didapat $r$ hitung $=0,797$, maka dapat disimpulkan bahwa Ho ditolak dan Ha diterima yaitu ada hubungan Percaya Diri dengan Hasil Belajar PKn Peserta Didik Kelas V SDN-4 Pahandut Palangka Raya Tahun Pelajaran 2016/2017.

Percaya diri adalah keyakinan yang dimiliki oleh seseorang (individu) atas kemampuan yang ada dalam dirinya untuk menghadapi berbagai masalah misalnya tetap tegar,sabar dan tabah dalam menghadapi masalah dan tidak tergantung pada orang lain (mandiri) serta selalu yakin dan optimis bahwa dirinya mampu mencapai tujuan yang diinginkan dalam hidupnya. Percaya diri juga merupakan sikap seseorang yang memiliki potensi diri yang telah dikembangkan, maka akan munculah perasaan bahwa dirinya memiliki kemampuan untuk melakukan tindakan yang telah diputuskan.

Hasil belajar adalah suatu proses belajar yang ditandai dengan adanya perubahan tingkah laku, pengetahuan, keterampilan dan kemampuan yang dimiliki peserta didik itu sendiri atau seorang (Individu) setelah ia menerima serta melakukan aktivitas belajarnya. Hasil belajar juga dapat dikatakan sebagai tingkat penguasaan yang dicapai oleh seseorang dalam mengikuti program belajar sesuai dengan tujuan yang ditetapkan. 
Dalam kenyataanya di sekolah rasa percaya diri yang dimiliki peserta didik mempunyai hubungan yang erat dengan hasil belajar. Peserta didik yang memiliki percaya diri yang tinggi akan mengetahui kelebihan yang dimilikinya, karena peserta didik tersebut menyadari bahwa segala kelebihan yang dimiliki. Maka dapat disimpulkan bahwa rasa percaya diri memiliki hubungan yang positif dengan hasil belajar peserta didik. Hal tersebut didasarkan oleh hasil-hasil penelitian yang terdahulu, antara lain :

Fitriani (2011) dalam penelitiannya menyatakan bahwa "hasil analisis data diperoleh $r$ hitung sebesar 0,517 dan $r$ tabel dengan $N=77$ dan taraf signifikansi $5 \%$ sebesar 0,227 sehingga $r$ hitung $>r$ tabel $=0,517>0,227$. Disimpulkan bahwa terdapat hubungan yang positif dan signifikan antara sikap peserta didik pada matematika dengan prestasi belajar peserta didik SDN-5 Kuala Pembuang Kabupaten Seruyan".
Fitri Albani (2011) dalam penelitiannya menyatakan bahwa "hasil penelitian ini diperoleh kesimpulan terdapat hubungan positif antara kepercayaan diri dengan prestasi belajar ekonomi peserta didik kelas X SMA Muhammadiyah 2 Palangka Raya, hal ini sesuai dengan hasil penelitian bahwa $r_{x y}$ sebesar 0,875 pada sampel sekaligus pada populasi, sehingga hubungan antara variabel kepercayaan diri dengan prestasi belajar ekonomi termasuk dalam kategori yang sangat kuat".

Tabel 2. Tabel Bantu Korelasi Product Moment

\begin{tabular}{ccccccc}
\hline No & $\begin{array}{c}\text { Kode } \\
\text { Siswa }\end{array}$ & $\begin{array}{c}\text { Skor Angket } \\
(\mathbf{X})\end{array}$ & $\begin{array}{c}\text { Hasil } \\
\text { Belajar } \\
\mathbf{P K n}(\mathbf{Y})\end{array}$ & $\mathbf{X}^{\mathbf{2}}$ & $\mathbf{Y}^{2}$ & $\mathbf{X Y}$ \\
\hline 1 & $\mathrm{~A}$ & 30 & 75 & 900 & 5625 & 2250 \\
\hline 2 & $\mathrm{~B}$ & 25 & 68,75 & 625 & 4726,5625 & 1718,75 \\
\hline 3 & $\mathrm{C}$ & 20 & 56,25 & 400 & 3164,0625 & 1125 \\
\hline 4 & $\mathrm{D}$ & 27 & 75 & 729 & 5625 & 2025 \\
\hline 5 & $\mathrm{E}$ & 29 & 81,25 & 841 & 6601,5625 & 2356,25 \\
\hline 6 & $\mathrm{~F}$ & 25 & 68,75 & 625 & 4726,5625 & 1718,75 \\
\hline 7 & $\mathrm{G}$ & 16 & 62,5 & 256 & 3906,25 & 1000 \\
\hline 8 & $\mathrm{H}$ & 32 & 93,75 & 1024 & 8789,0625 & 3000 \\
\hline 9 & $\mathrm{I}$ & 30 & 81,25 & 900 & 6601,5625 & 2437,5 \\
\hline 10 & $\mathrm{~J}$ & 33 & 75 & 1089 & 5625 & 2475 \\
\hline 11 & $\mathrm{~K}$ & 31 & 75 & 961 & 5625 & 2325 \\
\hline 12 & $\mathrm{~L}$ & 29 & 68,75 & 841 & 4726,5625 & 1993,75 \\
\hline 13 & $\mathrm{M}$ & 30 & 93,75 & 900 & 8789,0625 & 2812,5 \\
\hline 14 & $\mathrm{~N}$ & 32 & 81,25 & 1024 & 6601,5625 & 2600 \\
\hline
\end{tabular}




\begin{tabular}{|c|c|c|c|c|c|c|}
\hline 15 & 0 & 27 & 68,75 & 729 & 4726,5625 & 1856,25 \\
\hline 16 & $\mathrm{P}$ & 30 & 81,25 & 900 & 6601,5625 & 2437,5 \\
\hline 17 & $Q$ & 30 & 75 & 900 & 5625 & 2250 \\
\hline 18 & $\mathrm{R}$ & 34 & 81,25 & 1156 & 6601,5625 & 2762,5 \\
\hline 19 & $S$ & 32 & 81,25 & 1024 & 6601,5625 & 2600 \\
\hline 20 & $\mathrm{~T}$ & 29 & 68,75 & 841 & 4726,5625 & 1993,75 \\
\hline 21 & $U$ & 26 & 62,5 & 676 & 3906,25 & 1625 \\
\hline 22 & $\mathrm{~V}$ & 28 & 68,75 & 784 & 4726,5625 & 1925 \\
\hline 23 & W & 27 & 62,5 & 729 & 3906,25 & 1687,5 \\
\hline 24 & $x$ & 29 & 81,25 & 841 & 6601,5625 & 2356,25 \\
\hline 25 & $Y$ & 27 & 62,5 & 729 & 3906,25 & 1687,5 \\
\hline 26 & $z$ & 30 & 75 & 900 & 5625 & 2250 \\
\hline 27 & $\mathrm{AA}$ & 22 & 50 & 484 & 2500 & 1100 \\
\hline 28 & $A B$ & 26 & 68,75 & 676 & 4726,5625 & 1787,5 \\
\hline 29 & $\mathrm{AC}$ & 22 & 50 & 484 & 2500 & 1100 \\
\hline 30 & $A D$ & 27 & 68,75 & 729 & 4726,5625 & 1856,25 \\
\hline 31 & $\mathrm{AE}$ & 24 & 68,75 & 576 & 4726,5625 & 1650 \\
\hline 32 & $\mathrm{AF}$ & 18 & 50 & 324 & 2500 & 900 \\
\hline 33 & $A G$ & 30 & 75 & 900 & 5625 & 2250 \\
\hline 34 & $\mathrm{AH}$ & 20 & 50 & 400 & 2500 & 1000 \\
\hline 35 & $\mathrm{Al}$ & 30 & 93,75 & 900 & 8789,0625 & 2812,5 \\
\hline 36 & AJ & 24 & 68,75 & 576 & 4726,5625 & 1650 \\
\hline 37 & AK & 26 & 68,75 & 676 & 4726,5625 & 1787,5 \\
\hline 38 & $\mathrm{AL}$ & 32 & 81,25 & 1024 & 6601,5625 & 2600 \\
\hline 39 & AM & 24 & 68,75 & 576 & 4726,5625 & 1650 \\
\hline 40 & AN & 32 & 81,25 & 1024 & 6601,5625 & 2600 \\
\hline 41 & $\mathrm{AO}$ & 25 & 68,75 & 625 & 4726,5625 & 1718,75 \\
\hline 42 & $\mathrm{AP}$ & 30 & 81,25 & 900 & 6601,5625 & 2437,5 \\
\hline 43 & $A Q$ & 29 & 75 & 841 & 5625 & 2175 \\
\hline 44 & AR & 26 & 75 & 676 & 5625 & 1950 \\
\hline 45 & AS & 27 & 68,75 & 729 & 4726,5625 & 1856,25 \\
\hline \multicolumn{2}{|c|}{ Jumlah } & $\Sigma X=1232$ & $\begin{array}{c}\sum Y= \\
3237,5\end{array}$ & $\begin{array}{l}\sum X^{2}= \\
34444\end{array}$ & $\begin{array}{c}\sum Y^{2}= \\
237968,75\end{array}$ & $\begin{array}{l}\sum X Y= \\
90150\end{array}$ \\
\hline
\end{tabular}

\section{KESIMPULAN}

Berdasarkan hasil analisis data menggunakan rumus Korelasi Product Moment, maka penelitian ini dapat disimpulkan bahwa ada hubungan Percaya Diri dengan Hasil Belajar PKn
Peserta Didik Kelas V SDN-4 Pahandut Palangka Raya Tahun Pelajaran 2012/2013. Hal tersebut berdasarkan pada hasil analisis data yaitu $r_{x y}$ sebesar 0,797 yang berlaku pada sampel sekaligus pada populasi. 


\section{DAFTAR PUSTAKA}

Angreini, dkk., (2000), Kurikulum Pendidikan Sekolah Dasar, Jakarta : Grasindo.

Fitriani, (2011), Korelasi Sikap Peserta Didik Terhadap Matematika dengan Prestasi Belajar Matematika di SDN-5 Kuala Pembuang Kabupaten Seruyan (Skripsi), Palangka Raya : Universitas Muhammadiyah Palangkaraya.

Fitri Albani, (2011), Hubungan Kepercayaan Diri dengan Prestasi Belajar Ekonomi Peserta Didik SMA Muhammadiyah 2 Palangkaraya (Skripsi), Palangka Raya : Universitas Muhammadiyah Palangkaraya.

Nana Sudjana dan Ibrahim, (2001), Penelitian dan Penilaian Pendidikan, Bandung : Sinar Baru Algensindo.

Suharsimi Arikunto, (2002), Prosedur Penelitian, Jakarta; Rineka Cipta.

Thursan Hakim, (2005), Mengatasi Rasa Percaya Diri, Jakarta : Puspa Swara.

$\begin{array}{ccc}\text { Zamroni, } \quad \text { (2011), Definisi } & \begin{array}{r}\text { Pendidikan } \\ \text { http://definisi }\end{array} \\ \text { Kewarganegaraan, } & \text { Diakses } & 10 \\ \text { Pengertian.biogspot.Com, } & \text { Diaret 2012. }\end{array}$

